\title{
American Jews Beyond Judaism
}

\author{
Alexander H. Joffe
}

Published online: 21 May 2011

(C) Springer Science+Business Media, LLC 2011

Why do American Jews identify overwhelmingly with the Democratic Party? Why do they seemingly identify with left-liberalism and evince hostility toward conservativism? Is this stance an outgrowth of Judaism or a substitute for it, as Norman Podhoretz has argued? Is American Jewish liberalism a belief system that stands alone or is it instead part of a suite of bourgeois beliefs and behaviors, that is, culture? A striking parallel with recent Jewish history suggests the latter.

A series of essays by the late historian George Mosse presented an incisive portrait of German Jewry between the World Wars. Possessed by the German middle class ideals of bildung or self-cultivation, German Jews pursued what we would today call liberal ideals of self-improvement and the goals of social responsibility and German nationalism. By becoming more German than the Germans themselves, a portion of the Jewish community, including the wealthy and educated, sought full acceptance and participation as Germans. Embracing Enlightenment principles on the one hand, and emerging German nationalism on the other, Judaism was relativized, universalized, redefined and often discarded in the process. But as earlier ideals of bildung and nationalism narrowed with the rise of fascism and Nazism, discarding the former and mutating the latter into racism, Jews clung stubbornly and in vain to the ideals that had given them entre to German society and then the hope for the restoration for their abrogated emancipation. German Jews beyond Judaism was the title of Mosse's collected essays, and his message is as vital to understanding Judaism in today's liberal societies as it is for understanding the ashes of German Jewry.

\footnotetext{
A. H. Joffe $(\bowtie)$

56 Irving Place,

New Rochelle, NY 10801, USA

e-mail: alexjoffe@optonline.net
}

History does not repeat itself, but there are instructive parallels between German Jews of the late $19^{\text {th }}$ and early $20^{\text {th }}$ century and American Jews in the $21^{\text {st }}$. A significant portion of American Jewry is beyond Judaism in ways strikingly similar to their earlier German counterparts. Specifically, at the core of each Jewish experience lies the concept of bourgeois respectability. The desire to fit in with prevailing bourgeois ideals and society, which partially refracted intellectual culture was, and is, as compelling as the ideals themselves.

It must be emphasized that to draw analogies with German Jewry is not to portend similar outcomes today, particularly in the United States. American society (in the sense of traditions and institutions) could not be more dissimilar than that of Germany, as it is tradition of antisemitism. No accusations of incipient Nazism or blindness to the same are intended. But in recent centuries the Jewish response to modernity and post-modernity appears to trend in similar directions even as the larger context differs.

\section{Bildung}

In Germany of the 19th century nationalism conditioned society and culture. But upward social mobility also entailed carefully prescribed rules of behavior, central to which was bildung. Bildung meant not simply acquiring the education necessary for personal success but the cultivation of German middle class tastes and sensibilities, values and expressions, at that time on a Classical model. For Jews formally emancipated in the 1860 s and 1870s in German states and the Hapsburg Empire, it was a key mechanism that was an ideology and a lifestyle all in one. 
At one level this was simply acculturation of the sort that Jews and others have pursued since time immemorial as minorities. The sense of entering into broader German society by embracing German behavior, including speech and dress, concepts of appropriate masculinity and femininity, the valuation of arts and literature that glorified the German nation and nationalism, was profound. Enlightenment universalism that emphasized tolerance and rationality was meshed with Judaism to produce a 'religion of humanity.' At another level bildung also entailed leaving archaic and idiosyncratic Jewish practices behind, including dress and foodways but more importantly liturgy and the theology of Jewish particularity and exclusiveness. The movement to "Reform" Judaism was born precisely out of the 19th century impulse to update the religion, discarding what was not relevant and retaining a core universalistic message. At the same time, however, dedication to the German nation was a supreme value. Patriotism was internalized and also displayed, no more so that during World War I, when German Jews fought for the Kaiser as well as for the Austrian emperor.

The German Jewish experience stands in strong contrast to that of French Jews. There, republican ideals demanded the dissolving of all outward communal ties, not only for Jews but for other ethnic groups and regional peasants with their dialects and folkways. The end result of assimilation was somewhat the same as in Germany but the ideological attachment and social enthusiasm for republicanism differed from that of bildung. Republicanism was high, middle and low culture, the fabric of the new entity called France, while in German bildung was a bourgeois concept.

Intermarriage and demographic changes were major issues in later $19^{\text {th }}$ century and $20^{\text {th }}$ century Germany and many leading Jewish families approached the fin de siècle without any remaining Jewish members or allegiances. With the coming of Nazism of course these distinctions became academic. But for a period Jews were accepted into German society, or rather they forced their way in thanks to a remarkable and concerted effort. The 'German-Jewish synthesis' that produced contributors as varied as Heinrich Heine and Karl Marx, Sigmund Freud and Gustav Mahler, Theodor Herzl and Martin Buber, Franz Kafka, Walter Benjamin and Hannah Arendt, is a remarkable and singular achievement. This floruit of culture and thought, engagement with the questions of tradition and modernity, is unequalled anywhere in the past millennium of Jewish history, prior to the American experience.

But as Mosse emphasizes, it was an identity with a distinctive trajectory toward the left wing in the 20th century. Pursuing its own logic of a common humanity and individual autonomy, intellectual Jews aligned themselves increasingly with socialism and other left wing movements. Liberation from orthodoxies was a keystone of Weimer era culture, and Jews were active participants in efforts to build a new society free of domination. The Frankfurt school founded by Max Horkheimer and Theodore Adorno was perhaps the locus classicus of such thinking. Rejection of its bourgeois roots, with soul destroying capitalism and the oppressive structures of society, including conventional moralities, led to a rejection of liberalism and an emphasis on aesthetics, criticism and for some, revolution. The split between Walter Benjamin and Martin Buber in some sense exemplified this final phase; where the former chose universalism, the latter chose Judaism and Zionism. Perhaps their fates are also instructive. Benjamin, in flight, took his own life. Buber died of old age in Jerusalem.

But of course by that time Germany was a very different place. Mosse is at his most painfully eloquent describing the inability of German Jews to understand that the world had changed around them. While left wing Jewish intellectuals were spread among socialist or Communist camps, the majority of German Jews remained stolidly middle class in outlook and behavior. "Jews clung to an ideology that had been abandoned by most Germans and upheld it under conditions which should have made its failure obvious," writes Mosse, who adds "They lived the life of the cultured middle class even under the shadow of imminent death." German Jews misunderstood utterly the chauvinism and racist nationalism that rushed into the political void at the end of World War I. They failed to recognize how bildung was appropriated and misused by the far right, and their tradition of political naïveté left them ill-prepared to deal with National Socialism. A minority shifted to Zionism, and fewer still returned to religious orthodoxy. Most went to their deaths not understanding the demise of the humanist culture in which they were participants. That humanism, however, was one of the keys to the values of the rebuilt Federal Republic of Germany. As Mosse points out, "it was the German-Jewish Bildungsbürgertum which, more than any other single group, preserved Germany's better self across dictatorship, war, holocaust, and defeat." Perhaps in death German Jews helped make a lasting contribution to Germany.

\section{American Jews: Class and Adaptation}

The obvious must again be emphasized: the United States is not Germany, and there is no reason to think that national politics and culture in this country will generate fascism much less genocide. The issue instead is how emancipated Jews align themselves with local politics and culture.

American Jews were privileged by European standards. Legal discrimination was comparatively minor and while economic constraints were vast for the mass of immigrants in the later 19th century, the almost instantaneous contribution of 
Jews must surely be one of the more remarkable group success stories in history. Once informal institutional barriers were broken, commerce, the arts, science and all professions were flooded with Jews. Entirely new industries were created or perfected. And the Jewish attitude toward the American project was one of vast outpourings of gratitude and cash. Once economically secure, wealthy Jews made titanic contributions to educational, medical and cultural institutions. A walk across any university, hospital or museum amply confirms this. But tellingly, Jewish mega-philanthropy was, and is, directed primarily at non-Jewish causes.

Contributing to institutions of high culture confirmed the place of elite Jews in American society even as the majority of them struggled for economic survival and social acceptance. But Judaism was a stigma or impediment even for the wealthy. Following German practice, American Reform Judaism redefined religion into a series of ethical precepts while discarding ritual and parochial readings of Jewish texts. Americans of 'Hebraic persuasion' could more easily distance themselves from idiosyncratic origins and distinctive practices.

The successful German Jewish immigrants in 19th century American distanced themselves from Jewish practice and then from the mass of unsophisticated Jewish immigrants from Eastern Europe. That next wave of immigrants had no experience whatsoever of Reform Judaism; Orthodoxy was their only frame of reference. Many Jews moved to the Reform camp precisely because it freed them from the burden of tradition and practice. Others jettisoned Judaism altogether and embraced unfettered American lives. And in a strikingly bildung-like adaptation, Conservative Judaism developed around the turn of the $20^{\text {th }}$ century, emphasizing rationality and critical approaches to Jewish history and texts, a balancing act that encouraged engagement with modernity while preserving tradition. What it 'meant' to be Jewish was redefined continually from the moment Jews stepped onto the New World as Jews, as religious and political compromises were struck.

As with their German counterparts, American Jews engaged American culture and politics to maximize success and demonstrate dedication to the American project. Several contradictory strands comprised what it meant to be American for Jews. The successful among this next wave of Jews, such as the founders of the film industry, soon found it expedient to define themselves as Americans first, explicitly downplaying their Jewish backgrounds. 'Americanism' was a 1940s watchword; the nation with its adopted ideals, belief and origin story became the touchstone, which was preached in turn to all immigrants. This resort to nationalism also strikes a chord with bildung. Being a good Jew entailed submerging distinctiveness within the American whole with its cultural and political values, anti-fascism and capitalism chief among them. For wealthy moguls and Jews aspiring to upward mobility alike, downplaying Jewish distinctiveness in favor of bourgeois norms was a logical adaptation. For the working classes dedication to the New Deal and Roosevelt was a practical and ideological matter that flowed from class-consciousness.

The left-leaning inclinations of part of the American Jewish community were evident from the turn of the century. Jews played key roles in the Socialist and labor movements, and Communism was one of the great cleavages in American Jewish society from the 1930s through the 1960s. Jews were leaders of the movement, agents of the Soviet Union, and their fierce opponents. As with their earlier German counterparts, American Jews became Communists in part because the putative universalism and egalitarianism of the ideology seemed to mesh or even continue the ethnical precepts of Judaism. But Communism was also a community with norms, values, rituals and social relations. For those alienated from constrained religious backgrounds or communities, the appeal of this dimension alone was great.

The American Jewish cleavage over Zionism and then Israel must also be mentioned. The Jewish community was divided in part along religious lines; Reform Jews were neutral or anti-Zionist, while more religious Jews were more pro-Zionist. Socialists, bundists, ultra-Orthodox and others fell out on different parts of the spectrum according to their own religious doctrines or lack thereof. But religion was only part of the American Jewish equation regarding Zionism and then Israel. Another element was effectively nationalism. American Reform Jews embraced the doctrine of Americanism, since this seemed both an ethical doctrine and an avenue toward social acceptance. The foreign entanglement of the Zionist project threatened their own integration through 'dual loyalties' that they, as much as any other, continually alleged. It also compromised their religious deterritorialization and universalism, a concern they shared, albeit in different terms, with Communists. Ironically, if Reform Jews lost the battle over Israel's creation, in the long term they won the war regarding universalism, which in turn has shaped Jewish attitudes toward Israel in the 21 st century.

But in the aftermath of World War II America society changed dramatically and the possibilities for American Jews broadened. New educational opportunities, expanding economies, and broader upward mobility lifted more Jews out of poverty into the expanding middle class. Upward mobility, movement and suburbanization played critical roles. New and old suburbs and uptown neighborhoods into which Jews moved were sites of social mobility for a new matrix of educated Jews, who conformed to the increasing universalized values of those settings. As the 1960s wore on came a new set of upper middle class intellectualized values, less parochially American and more international in orientation. Jewish participation in the civil rights move- 
ment gave way to the anti-war movement. Opposition to the Vietnam War provided ample opportunity for anti-American anger, and generational resentment against the suburban Jewish bourgeoisie. Pure rejection of tradition was also afoot, both generally and within the Jewish community. Sexual liberation redefined gender roles within or against the religious tradition. And throughout, the universalization of Jewish tradition was deliberately engineered, as a way to both broaden the tradition and encompass new bourgeois values and to satisfy a community nurtured on those values. Today over four million of the five or six million Jews in America live in and around just eight major urban areas.

\section{Living with Contradiction}

With the late 20th century partitioning of American society, thanks to vertical and horizontal growth, a knowledge based economy and globalization, the concept of bourgeois respectability - in terms of behavior, self-image and prevailing morality - is set not by doctors and lawyers or even hedge fund managers but by coastal ideocracies. The interlocking directorates of professors, mainstream and elite media, artists and activists, and human rights professionals, have redefined upper middle class urban and suburban American life. American Jews have adapted to this culture accordingly.

Much of this culture is well understood. Self-realization and self-satisfaction became paramount goals after the 1960s. Universities became test beds for social engineering schemes to manufacture equality. Free speech was dramatically narrowed as 'hate speech' was defined as sin and tantamount to or a precursor of "hate crimes." All lifestyles and viewpoints were not only regarded as intrinsically equal, but some, by virtue of having once been repressed or outlawed, were more equal than others. A general atmosphere of redress of Western sin took hold, and post-colonial guilt pervaded elite institutions along with a generalized suspicion of capitalism. Feelings were elevated to the position of highest importance and transgressions against others' feelings were regarded as a form of sin. Guilt and unspoken cognitive dissonance are the driving ideological forces, while materialism remains its foundation.

The New Deal and the Roosevelt administration were also responsible for a remarkable transformation in Jewish attitudes toward power. Where in other times and places Jews largely avoided the state when they could and negotiated with it when they had to, in the United States - as full participating citizens, not emancipated ones - they embraced both the state and the practice of politics. The implications of this are still felt today. State power is applauded (at least under Democratic administrations) and the state's role as provider and protector is deemed legitimate and necessary. Political power, in terms of electoral participation and government service, is also applauded, as is interest group politics.

But the obverse of this is that other forms of power, first of all individual self-defense, are frowned upon. So too, increasingly, is pursuit of self-interested communal, as opposed to universal, interests. Jews must trust the state and more recently the supra-state as their ultimate protectors rather than themselves or their neighbors. Hard power is distrusted while soft power is celebrated. Gun ownership is anathema, military service is unworthy, and negotiation toward consensus is prized above all. These are also regarded as fundamental premises shared by all civilized peoples, even if they declare otherwise. But the dependence of American Jews on the state appears to be a form of demonstrating not allegiance to the American project but a commitment to the collective wisdom and mercy of government leaders of the ideocratic class, who are assumed to have the best interests of all at heart.

Twenty-first century American urban and suburban upper middle class is predominantly liberal and Democratic. It is conflicted about its mobility and success and is dedicated to the expansion of a rights culture that will redress past injustices toward minorities. At its most extreme it can be caricatured as possessing a limited number of sacraments, affirmative action, abortion, judicial activism, and multilateral foreign policy. To this many be added the Arab-Israeli peace process, and the ethical equality of all cultures and religions. To some extent these meshed with Jewish communal experiences, such as joining with other minorities to fight racial and ethnic discrimination, and could be harmonized broadly with Jewish values. But as much as anything professing these values is the price of acceptance into respectable society.

In the United States the ideals of modern leftliberalism-emphasizing equality rather than liberty, redistributive justice rather than impartiality, and engineered tolerance - increasingly prevail over classical ideals of liberty, self-reliance, and critical judgment, at least within bourgeois culture. For many Jews and others nation-states are passé if not retrograde. Also on the rise is transnational progressivism, an ideology that may also describe a class, where international allegiances and institutions rather than local nation-states, have become the frame of reference and center of allegiance for self-described 'global citizens.' 'Think globally, act locally,' is part of an equation, which has, in Jewish terms been assimilated to part of Hillel's saying 'And when I am for myself, what am 'I'?'

At the same time, whatever enthusiastic nods there might be toward 'green' or 'sustainable' lifestyles there is no discernible trend away from materialism, among Jews or anyone else, only perhaps the implicit belief in the role of government as the compensatory mechanism to 'lift all boats,' 'prevent global 
warming,' and alleviate guilt. The contradictions arising from upper class materialism may thus be addressed by faux collectivism and solidarity and centralized power but little material sacrifice beyond higher taxes. Ideologies that offer expiation play a critical role, especially to the young, who with their adolescent revulsion at their own privilege and difference, seek out ways to distance themselves from their parents, but yet remain in or close to their material sphere.

Social activism in the guise of 'tikkun olam' takes Jews to New Orleans or to Darfur in pursuit of giving aid and creating a sense of self beyond the Jewish community or experience. Rhetorically grounded, however nominally, in Jewish traditions these concepts have nothing to do with Judaism as a whole but rather derive from highly selective readings of certain Prophets, promulgated largely by Reform Judaism. But they are another gloss for Jews who seek an identity within and acceptance by post-national bourgeois society. Jewish knowledge is abysmally low, and in any case strong religious beliefs and rigorous practice are both difficult and off-putting. Judaism itself appears regarded, by an unknown majority of American Jews, as something ranging from a parochial embarrassment at worst to a cultural option at best. Where once the hyphenated identity was the vogue now identities are so fluid as to be a form of apparel, to be worn situationally and dropped when necessary.

Israel inevitably enters the equation. Being Jewish and a nation-state are two automatic strikes in the eyes of the stream of bourgeois thinking outlined here. Two forms of parochialism and exclusiveness are made worse by the recourse to force, which appears to perfectionist pacifists as militarism and barbarism. The terms under which Israeli society lives and thinks are simply so alien to the majority of American Jews that there are few grounds for dialogue. A more nuanced view would stipulate that American Judaism of the post 1948 vintage saw the triumph of Zionism on the fields of battle and ultimately domestically against liberal, mostly Reform Jewish opponents. But this cult of Israel, which lasted perhaps until the 1970 s or 1980 s, was a convenient displacement of Jewishness on to Israel by American Jews. Contributing to the UJA was a sufficient exercise of Jewishness for all too many, who then went on with their lives, creating few Jewish foundations for their children. To be sure, a vast Jewish education infrastructure was also built, both to create foundations and to remediate shaky ones. But the Jewish community was no longer self-contained and ideological influences streamed in from everywhere. Now Israel is increasingly irrelevant or worse, anathema to a wide swath of American Jews.

The assertion that American Jews are liberals because they believe in liberalism even though it works to their disadvantage is misplaced. American Jews earn like Episcopalians and vote like Puerto Ricans because it established their liberal bona fides with other sectors of society, both dominant and minority, and allayed class guilt. Jewish liberalism helped pave the acceptance of Jews into American liberal society, the biggest and most elite country club of all. To that end it has been successful. And to the extent that Jewish beliefs and practices, and Israel, have to be sacrificed, they will be. American Jews have and will continue to divest themselves of their Judaism, and redefine it in universal and non-Jewish terms, for the sake of what may simply be called assimilation. That they are assimilating into a particular segment of American and global society is no matter. But what is the future of that segment?

\section{Challenges to the Progressive Paradigm}

The example of German Jews beyond Judaism looms. Just as German Jews saw the terms of bildung change at the turn of the 20th century, so too have American Jews begun to see changes in American and global society. For one thing, the terms of acceptance have turned sharply higher.

Israel is a flashpoint. Condemnation of Israel is routine for transnational progressives for reasons discussed above. In turn, repudiation of Israel is becoming a requirement for being accepted into bourgeois culture. This mirrors the conditions of the non-Jewish Jew as defined by Isaac Deutscher, who believed the highest expression of Jewishness was to give up Judaism in favor of internationalism. In this formula, Israel of course must go. Indeed, precisely those terms, not incidentally represented strongly in Communist thought on Judaism, are heard increasingly from both progressive political and cultural quarters. To be accepted as 'Jews,' Jews must give up everything specific and unique about being Jewish. But American support as a whole for Israel is at an all-time high, as Americans outside the bourgeois classes recognize common values, experiences, and threats in Israel, not least of all similar beliefs in strong national identities. Here, all too many American Jews are out of step with their own countrymen.

The irony of the American Jewish bourgeoisie aligning itself with Communist-inspired ideology and movements has been played out again and again, most recently in the 1950s and 1960s. The glaring contradictions here of ascribing to an acidic universalism that seeks to dissolve difference in the name of equality, but whose adherents strive to retain their class privileges is hardly novel either. In a sense the entire post-war European experience is based on this theme, writ large. There was never anything distinctively Jewish about it, except in the specific terms of self-loathing and hypocrisy. So it remains today. American Jews beyond Judaism do so in the name of the universal, but seek the class privileges to which they have become accustomed. Europeans and global elites will adjust. Will American Jews?

Like Europeans, that class of Americans and American Jews, highly educated, post-national and deterritorialized, 
with elastic and shifting affiliations, must now also confront a new phenomenon, the return of nationalism. The European Union is convulsing after the economic collapse of Greece, but the trends toward nationalism were present long before. In Hungary, Scotland, and Ukraine nationalist parties with messages that range from separatism to fascism have moved to the center stage. The Czechs and Slovaks have long since divorced. Hindu nationalists of the BJP have long held power across India. Chinese nationalism has replaced Communism as the glue holding the different parts of China together. And the supra-tribe of Islam is resurgent everywhere, forcing states to redouble their defenses.

Ironically, of course, the only place on earth where 'one state' remains a left-liberal requirement is 'Israel-hyphenPalestine.' Everywhere else peoples, primordial and invented, are going their separate ways. Western ideocracies have begun to adapt to this reality by a return to 'third worldism,' the belief that nationalism is a historical stage for downtrodden nations dominated by Western imperialists (especially the Great and Little Satan), and through the concept of 'responsibility to protect,' which demands liberal humanitarian intervention against certain flamboyantly bad dictators. In the U.S. the economic populism of the 'Tea Party' has features of both renewed nationalism and class warfare against the idea-setting and bureaucratic cadres. ROTC is returning to Ivy League campuses, and patriotism may even return to the American suburbs. Ideocracies rationalized the failure of Communism and will do so with socialism and transnationalism. The only question is how, and what sacrifices Jews will be called on to make in order to remain devotees.

Another global trend that American Jews and other members of their class are missing is the explosive growth of southern Christianity. In Africa alone there are now over 400 million Christians, mostly evangelical and charismatic, comprising over $46 \%$ of the population. Similar trends are underway in Central and South America, as well as China, where there are estimated to be between 70 and 130 million Christians. Indeed, even in Europe itself, mainline Protestant denominations and Catholicism are being outstripped by rapidly growing evangelical mega-churches. The trope that Islam is the fastest growing religion is the world is far from true, and its implications, somewhere between fascination and accomodation to defeatism and appeasement, mask the true shape of world religious and demographic development. American Jewish indulgance of Islam will be challenged by growing confrontations at home and abroad.

\section{Hard Choices}

American Jews ascribing to old and discredited beliefs risk being overtaken by events. American Jews, however, could take the initiative and realign themselves with other parts of
America, towards the political and social centers. Leaving their social class means critically examining accepted behaviors and values individually, giving up the religionlike truths and certainty, and risk of losing a network of friends and relations. It means accepting the legitimacy of some values of 'middle America.' It demands overcoming the reflexive revulsion too many Jews exhibit toward believing Christians. Fundamentally it means becoming unlike one's social, economic and intellectual class.

More positively, leaving the bourgeoisie means reembracing the two party system and the Constitution rather than following the muscle memory of the Democratic Party, big labor, and legislating from the bench. Questioning the conceit of the liberal arts is already underway as a function of the higher education bubble and the visceral hatreds it encloses. Self-reliance and smaller government, localism, the primacy of the individual rather than the collective, and a sense of the American and Jewish collectives as peoples with shared values and fates, all these and more would have to be examined and inculcated by apostate Jews.

Such a turn to the American cultural and political center may be occurring haphazardly among American Jews. The catastrophic economics of being Jewish in America, paying premiums for food and religious education, is driving more Jews out of the upper middle class than ever before, although to what is unclear. Keeping kosher and day schools are crushing burdens not easily shouldered. The Obama administration's antipathy to Israel is also playing a role. But the reception of Sarah Palin is equally telling; she remains a reviled figure for many Jews, along with other believing Christians who have the temerity to support Israel along with American values. Still, the answer is not to be found by blindly embracing the cultural and political right. In any case, it may be too late for any answer that preserves the American Jewish community in any familiar form.

\section{Fate and the Future}

The center has not held. And the sad truth is that the demographic future of American Jews rests in the hands of the modern Orthodox and right wing Orthodox, who are the only Jews who average more than two children. The further right they are religiously, the less inclined than other Jewish cohorts they are to accept the class and status consciousness that characterizes liberal American Jews. But at the same time they appear increasingly less inclined to engage with the secular world or America as a whole. The greater their religiosity, the more their religious values are a barrier to the American center, the same way that liberal values are, only with the added deficit of non-participation. And as Jewish numbers and wealth decline, so does Jewish political and cultural influence, to the detriment of America and Israel. 
The fate of American Jews has yet to be played out. How Jews of a new middle or even working class might retain their American and Jewish identities, separately and as a unity, is unknown. Would the process of 'Americanism' again lead to assimilation? Perhaps. Shrinking numbers and diminished dedication to both America and to Judaism are unlikely to be offset by the Orthodox remnant. Perhaps another Haskalah will develop there a few decades in the future. But today, continued dedication to bourgeois culture, including leftliberal ideology, will hasten the fall of the community as a whole into political and cultural irrelevance. But it is cold comfort to suggest that the unparalleled contribution of Jews to America in every conceivable field will be rediscovered and appreciated at some point in the future. Some of that earlier universalism, an American Jewish Bildungsbürgertum, produced some of what is best in American culture, art, literature, education, science, philanthropy and dedication to the public good. Ironically, some of those same impulses precipitated the current crisis.

American Jews will suffer a fate altogether different from their liberal German predecessors. The present blindness will result in gradual and painless extinction, rather than an agonizing catastrophe. But relative pain is a measure of fortune, not wisdom. For Israel the future may be more jarring, particularly as a large portion of American Jews increase the distance from their coreligionists and fellow members of the Jewish nation. Lack of a national identification, American or Jewish, is perhaps the most striking component of liberal Jewish culture. For the remnant, illiberalism appears to be a likely future.

The temptations of America have been many but the goldineh medineh may well be the greatest haven Jews have known in the entirety of their history. The AmericanJewish synthesis and Jewish contribution are arguably without parallel. But aligning with segments of American culture intent on dissolving precisely those things that make America uniquely strong has been disastrous, if superficially well-intentioned. In the end, this episode of Jewish assimilation is like countless others throughout history, with the difference that it has contributed to the end of the society into which Jews have assimilated. America as a whole will likely change course and survive. For American Jews reversing course may be too little, too late.

Alexander H. Joffe, Advisory Editor of Society, is a Research Scholar with the Institute for Jewish \& Community Research in San Francisco. The author thanks Rachel Hallote, Cynthia Ozick, Greg Seinfeld, and Gary Waller for their comments on earlier versions of this essay. 